\title{
Dominika Czakon
}

https://orcid.org/0000-0002-0300-9436

\author{
badaczka niezależna \\ e-mail: dominika.czakon@gmail.com
}

\section{Natalia Anna Michna}

(1) https://orcid.org/0000-0001-9334-474X

\author{
Instytut Filozofii Uniwersytetu Jagiellońskiego \\ e-mail: natalia.michna@uj.edu.pl \\ Leszek Sosnowski \\ https://orcid.org/0000-0002-7259-2688
}

\author{
Instytut Filozofii Uniwersytetu Jagiellońskiego \\ e-mail: leszek.sosnowski@uj.edu.pl
}

\section{Z KORESPONDENCJI NAUKOWCÓW: STEFAN MORAWSKI I ROMAN INGARDEN}

\section{From the Correspondence of Scientists: Stefan Morawski and Roman Ingarden}

\begin{abstract}
The article is a scientific overview of the preserved correspondence of Stefan Morawski and Roman Witold Ingarden from 1961 to 1969. The 1960s were a period of important events and changes in both the lives of Ingarden and Morawski. In both cases, the background was the political situation in Poland, of which - in a certain sense - both philosophers became victims. Although their attitude and political commitment differed - Ingarden remained indifferent to politics, unlike Morawski, who belonged to the party - it turned out that both of them suffered harassment from state officials. In addition to discussing scientific issues, the letters of both philosophers contain a lot of information on current and important issues for them directly, and indirectly for the Polish scientific community of that time. Therefore, the article discusses publishing issues, organizational and scientific matters related to conference trips, and scientific issues related to the reviews of master's, doctoral and postdoctoral dissertations. The historical background and private fate of both philosophers were also taken into account, which is not insignificant for their scientific work and mutual relations.
\end{abstract}

Keywords: Roman Ingarden, Stefan Morawski, correspondence, Jagiellonian University, University of Warsaw, aesthetics 


\section{Wprowadzenie}

Zachowana w Archiwum Nauki PAN w Krakowie korespondencja Romana Witolda Ingardena (1893-1970) i Stefana Morawskiego (1921-2004) nie jest zbyt obszerna, lecz jest bogata merytorycznie. Liczący około 50 listów i kartek pocztowych zbiór przedstawia zapis kontaktów zawodowych i naukowych dwóch wybitnych filozofów i estetyków, badaczy znanych i cenionych w Polsce, ale także poza jej granicami. Ingarden przez większą część zawodowego życia, to jest od 1945 roku aż do śmierci w roku 1970, związany był z Uniwersytetem Jagiellońskim jako wykładowca i kierownik Katedry Filozofii ${ }^{1}$. Morawski natomiast rozwijał swoją samodzielną i dojrzałą działalność naukową, pracując na Uniwersytecie Warszawskim jako wykładowca (od 1956 r.) i kierownik Katedry Estetyki (w latach 1962-1968). Obaj badacze byli aktywnymi uczestnikami, jak również twórcami polskiego i międzynarodowego życia naukowego i kulturalnego. Morawski, obok Zofii Lissy i Stefana Żółkiewskiego, należał do komitetu redakcyjnego „Estetyki” (od momentu jej powstania w 1960 r.), przekształconej następnie w „Studia Estetyczne”. Ingarden natomiast pełnił ważną funkcję redakcyjną w „Studia Philosophica”, które zostały zamknięte po opublikowaniu dwóch tomów, po II wojnie światowej, a także w „Ruchu Filozoficznym”, którego od 1958 roku był regionalnym przedstawicielem w Krakowie 2 .

Zbiór omawianej w niniejszym artykule korespondencji pochodzi z lat 1961-1969, a więc obejmuje ostatnią dekadę życia Ingardena. Był to czas ważnych wydarzeń i zmian zarówno w życiu Ingardena, jak i Morawskiego. W obu przypadkach tłem była sytuacja polityczna w Polsce, której - w pewnym określonym sensie - obaj naukowcy stali się ofiarami. Choć różniły ich postawa i zaangażowanie polityczne - Ingarden pozostawał obojętny wobec polityki, odmiennie niż Morawski, który należał do partii - okazało się, że obu dotknęły szykany ze strony urzędników państwowych.

Wspomniany zbiór listów odsłania również inny element podobieństwa między badaczami. Lektura korespondencji pokazuje, że właśnie wtedy współpraca zawodowa i naukowa między nimi umocniła się i przerodziła w relację życzliwego koleżeństwa i dyskusji filozoficznej. Obraz tej relacji nie jest całkowicie jednoznaczny, wielokrotnie bowiem w zachowanej korespondencji pojawiają się wątki krytyczne i polemiczne, jednak - co należy podkreślić - zawsze o charakterze merytorycznym. Morawski jako przedstawiciel pokolenia urodzonego tuż po I wojnie światowej, prawie 30 lat młodszy od Ingardena, z szacunkiem i uznaniem traktował filozoficzny

1 Na marginesie warto odnotować, że kiedy w latach 50. XX wieku, w wyniku represji komunistycznych, Ingarden utracił Katedrę na Uniwersytecie Jagiellońskim i pozbawiono go prawa do prowadzenia zajęć dydaktycznych, decyzją ministerialną został formalnie przeniesiony do Instytutu Filozofii Uniwersytetu Warszawskiego. Zob. Roman Ingarden - życie, Cyfrowe Archiwum Romana Ingardena (dostęp: 4.04.2021).

2 D. Czakon, N.A. Michna, Roman Ingarden-życie i dzieło w subiektywnym ujęciu [w:] L. Sosnowski (red.), Spotkania. Roman Ingarden we wspomnieniach, Księgarnia Akademicka, Kraków 2020, s. $23-24$. 
i estetyczny dorobek autora Das literarische Kunstwerk. Jednocześnie, z właściwą dla siebie dociekliwością i zacięciem, podejmował próby krytycznego przekroczenia estetycznych propozycji i rozstrzygnięć obecnych w poglądach Ingardena, stąd liczne uwagi polemiczne skierowane wprost do niego lub poprzez jego uczniów.

Poza dyskusją dotyczącą kwestii stricte naukowych listy obu naukowców zawierają wiele informacji na temat spraw bieżących i ważnych dla nich bezpośrednio, a dla środowiska naukowego pośrednio. Na plan pierwszy wybijają się oczywiście sprawy zawodowe, zyskujące na znaczeniu po przejściu Ingardena na emeryturę, a więc w okresie przeprowadzanych zwolnień jego współpracowników. Są to też jednak kwestie publikacyjne, stanowiące wówczas duży problem ze względu na finanse, ale również określone oczekiwania lub wręcz wymagania stawiane bądź przez Ingardena jako autora bądź Morawskiego jako redaktora czasopism. W korespondencji pojawiają się ponadto sprawy organizacyjno-naukowe związane z wyjazdami konferencyjnymi, co w tamtym czasie łączyło się z koniecznością pokonywania szczególnych trudności. Omawiane są także kwestie naukowe związane z recenzjami rozpraw magisterskich, doktorskich i habilitacyjnych, które w konsekwencji dotyczyły zazwyczaj awansów na stanowiska uczelniane.

\section{Sprawy zawodowe}

Zachowana korespondencja Ingardena i Morawskiego rozpoczyna się w 1961 roku. Dwie kwestie zwracają w niej uwagę. Po pierwsze wątki osobiste były jedynie delikatnie sugerowane, mieszcząc się $\mathrm{w}$ pobocznym nurcie korespondencji. Po drugie wymiana listów między badaczami zaczyna się stosunkowo późno.

Ingarden i Morawski zaraz po II wojnie światowej podjęli pracę akademicką w tym samym mieście, w Krakowie. W przypadku Ingardena decyzja o przyjeździe do Krakowa była dość oczywista: Uniwersytet Jana Kazimierza we Lwowie nie należał już do Polski, więc filozof wrócił do rodzinnego miasta, z uczelnią o długich, naukowych tradycjach. W przypadku Morawskiego sytuacja wyglądała nieco inaczej. Tuż po wojnie jako młody asystent jeszcze bez tytułu magistra rozpoczął pracę dydaktyczną na Uniwersytecie Warszawskim. W latach 1947-1949, już jako doktor, pracował w Wyższej Szkole Nauk Społecznych w Krakowie, a następnie kierował Katedrą Podstaw Marksizmu-Leninizmu na Uniwersytecie Jagiellońskim³, prowadząc równocześnie wykłady w trzech innych tutejszych uczelniach, mianowicie

3 Zob. Stefan Morawski - estetyk, z którego zostat 'oczyszczony'UWwr. 68, https://lustronauki.wordpress.com/2009/01/23/stefan-morawski/ (dostęp: 13.04.2021). Warto tu dodać, że Katedra Podstaw Marksizmu-Leninizmu powstała w 1951 r. na miejsce Katedry Filozofii, a Morawski kierował nią przez rok. Zob. R. Kuliniak, M. Pandura, Roman Witold Ingarden (1893-1970), „Przegląd Filozoficzny - Nowa Seria” 2020, nr 29 (4), s. 41. Następnie Morawski został usunięty za publikację pracy o estetyce marksistowskiej, która została skrytykowana w „Trybunie Ludu”. Katedra została zlikwidowana w roku akademickim 1956/57 i od następnego roku reaktywowano już dwie, oddzielne katedry: Filozofii, którą kierował Ingarden, i Historii Filozofii, którą kierowała Izydora Dąmbska. 
w Wyższej Szkole Muzycznej, Wyższej Szkole Teatralnej i Akademii Sztuk Pięknych $^{4}$. Następnie we wrześniu 1955 roku, już po swojej habilitacji, Morawski wziął udział - wraz z Ingardenem i Władysławem Tatarkiewiczem - w III Kongresie Estetyki w Wenecji.

Powyższe fakty biograficzne zostają tu przytoczone po to, by pokazać, że znajomość obu filozofów mogła zacząć się znacznie wcześniej niż omawiana w artykule korespondencja z lat 60. XX wieku. Trudno oczywiście przyjąć, że w okresie krakowskim ich kontakty mogły być towarzysko bliskie, dzieliła ich bowiem zbyt duża różnica wieku, a także znaczące różnice światopoglądowe. Trzeba pamiętać, że Morawski należał w tym okresie do PPS, a następnie PZPR, podczas gdy Ingarden deklarował, że filozof nie może się angażować w politykę z powodów zasadniczych. Autor Das literarische Kunstwerk niezmiennie utrzymywał, że wymagająca bezstronności praca naukowa, a także sama idea uniwersytetu, wykluczają jakiekolwiek zaangażowanie polityczne. Jednak wspólny wyjazd konferencyjny, oznaczający podobieństwo zainteresowań i badań naukowych, mógł już sprzyjać zadzierzgnięciu bliższych więzów koleżeńskich, tym bardziej że Morawski uzyskał w tym czasie habilitację.

Wróćmy więc do samej korespondencji. Początkowo jej ton jest mocno formalny, chociaż obok omawiania spraw naukowych i organizacyjnych dotyczących życia akademickiego pojawiają się także zwroty o charakterze mniej oficjalnym czy nawet humorystycznym. Zapowiadając bowiem napisanie recenzji rozprawy habilitacyjnej doktora Jerzego Gałeckiego, Morawski pozwala sobie na przywołanie dowcipnego zwrotu z bajki Alana Alexandra Milne’a: „(...) by stwierdzić, że praca, którą przeczytałem, zasługuje na miano habilitacyjnej, trzeba by wiedzieć małe «co-nie-co» (proszę wybaczyć ten ulubiony zwrot Kubusia Puchatka) o całym poprzednim dorobku p. Gałeckiego"5. To oczywiście nie przeszkadzało Morawskiemu w zachowaniu krytycznego dystansu w stosunku do tez przedstawionej rozprawy i postawienia szczegółowych zarzutów merytorycznych.

List z 25 stycznia 1964 roku rozpoczyna wątek bolesny dla Ingardena, który z dwóch przynajmniej powodów zasługuje na pogłębioną uwagę, to jest społeczno-akademickich i naukowych. W pierwszym przypadku chodzi o kolejne czystki, podejmowane na uniwersytetach po II wojnie światowej, w tym wypadku na Uniwersytecie Jagiellońskim. Morawski donosi bowiem w liście o wizycie i spotkaniu w Warszawie z dr Marią Gołaszewską, która przedstawiła mu ówczesną sytuację w Krakowie:

Zob. P.J. Przybysz, Stefan Morawski 1921-2004 [w:] Portrety Uczonych. Profesorowie Uniwersytetu Warszawskiego po 1945, Warszawa 2016, s. 298 (dostęp: 13.04.2021).

4 Informacje biograficzne zostały zaczerpnięte z: P.J. Przybysz, A. Zeidler-Janiszewska, Stefan Morawski - wstępny szkic do portretu [w:] S. Morawski, Wybór pism estetycznych, oprac. P.J. Przybysz, A. Zeidler-Janiszewska, Universitas, Kraków 2007, s. VIII-XVIII.

5 List S. Morawskiego do R. Ingardena z 7 grudnia 1961 r. [w:] Cyfrowe Archiwum Romana Ingardena (dostęp: 4.04.2021). We wszystkich cytowanych listach zachowano oryginalną pisownię. 
Miałem w [Warszawie] wizytę dr. M. Gołaszewskiej. Raczej smutną. Orientuję się, że w Krakowie zachodzą jakieś ponowne usunięcia. Wątpię czy byłbym w mocy cokolwiek pomóc. Jeśli już ktoś może współdecydować to prof. Schaff' .

Pewne punkty listu wymagają poszerzonego komentarza. Przede wszystkim przytoczony powyżej fragment zaskakuje w kilku miejscach uwagami Morawskiego. Fakt, że ośrodek krakowski zwrócił się do niego z prośbą o pomoc, świadczy o tym, że Ingarden i jego współpracownicy wiązali z Morawskim określone nadzieje na uzyskanie tej pomocy. Sytuowali go w grupie partyjnych naukowców o wpływowej pozycji w kręgach politycznych. Kilka osób z grona współpracowników Ingardena podlegało mocnej presji uczelnianej organizacji partyjnej, co było faktem znanym - zresztą podobne sprawy miały też miejsce w innych uniwersytetach. Gdy Morawski pisze, że wątpi, by mógł pomóc, to nie ma podstaw, by kwestionować jego słowa. Gdy natomiast pisze: „orientuję się w jakichś usunięciach”, to nie jest to wyraz faktycznej wiedzy o sytuacji w Krakowie, lecz przyswojenia sobie ogólnej informacji przekazanej mu przez Gołaszewską. To zaskakująca „orientacja” w nieorientowaniu się, gdyż (ponad pół roku wcześniej niż datowany jest list) Ingarden, osiągnąwszy 70. rok życia, przeszedł na emeryturę, co było początkiem działań - przy pełnym poparciu wspomnianego właśnie Adama Schaffa - ze strony uczelnianych urzędników partyjnych wymierzonych w jego (Ingardena) zespół.

Komisja Kwalifikacyjna Uniwersytetu Jagiellońskiego wystąpiła wówczas o usunięcie z pracy dwóch osób: dr Janiny Makoty i prof. Izydory Dąmbskiej - jako rezultat negatywnych opinii sporządzonych przez $\mathrm{POP}^{7}$ UJ. Bez znaczenia były tu pozytywne fakty przemawiające na rzecz obu filozofek, jak zaangażowanie dydaktyczne i bardzo dobre opinie studentów na ten temat, dorobek naukowy czy rozwijane badania filozoficzne ${ }^{8}$. Żadnego również znaczenia nie miało stanowisko Rady Wydziału Filozoficzno-Historycznego UJ, o czym pisała w swoim liście pożegnalnym do tejże Rady Dąmbska: „Pani dr Makota, podana była do awansu na stanowisko adiunkta, awansu dotąd nie zatwierdzonego mimo dwukrotnej uchwały Rady Wydziału, i któ-

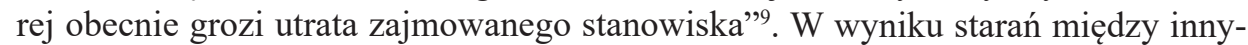
mi Ingardena i Dąmbskiej Makota została na krótko uratowana, otrzymała bowiem roczne przedłużenie z jednoczesną degradacją na stanowisko starszego wykładowcy. Było to tylko odroczenie - w 1964 roku utraciła definitywnie posadę akademicką.

$6 \quad$ List S. Morawskiego do R. Ingardena z 25 stycznia 1964 r. [w:] ibidem.

7 POP (podstawowa organizacja partyjna) - najmniejsza jednostka (komórka) Polskiej Zjednoczonej Partii Robotniczej (sprawującej władzę w Polskiej Rzeczypospolitej Ludowej). Podstawowe organizacje partyjne istniały w zakładach pracy, uczelniach i instytucjach kulturalnych w latach 1949-1989. Za: https://pl.wikipedia.org/wiki/Podstawowa_organizacja_partyjna (dostęp: 23.10.2021).

8 Więcej na temat sytuacji Janiny Makoty w tamtym czasie zob. J. Makota, Studia to nie musztra żotnierska... [w:] L. Sosnowski (red.), Spotkania..., op. cit., s. 207-222.

9 J. Perzanowski, Izydora Dambska [w:] J. Miklaszewska, J. Mizera (red.), Złota Księga Jubileuszowa Wydziatu Filozoficznego Uniwersytetu Jagiellońskiego, Księgarnia Akademicka, Kraków 2000, s. 323. 
W równie trudnej sytuacji znalazła się Dąmbska. Decyzja o jej przeniesieniu do Instytutu Filozofii i Socjologii Polskiej Akademii Nauk przyszła z Warszawy i była równoznaczna z utratą pracy na uczelni i tym samym utratą kontaktów ze studentami. Jak pisał jej student i uczeń Jerzy Perzanowski: „(...) ówczesny rządca filozofii polskiej [A. Schaff - red.] wydał rozkaz oczyszczenia z miazmatów filozofii studium filozoficznego UJ i zdecydował odsunięcie prof. Dąmbskiej od nauczania akademickiego" "10. Dąmbska z godnością przyjęła wyrok i przeniosła pracę akademicką do swojego domu przy ulicy Podwale 1; były to tak zwane privatissima, na których spotykała się grupka jej studentów. To o nich pisała: „,...) głęboką troską napawa mnie też sytuacja młodzieży, którą przez te lata się opiekowałam, zwłaszcza los studentów kończących obecnie czwarty rok studiów, którzy wszyscy (w liczbie 12 osób) pod moim kierunkiem piszą swe prace magisterskie. Ta młodzież jest żarliwa w swym filozofowaniu"11.

Odnotujemy dla ścisłości, że akademicki los obu filozofek podzieliło jeszcze kilku innych badaczy, związanych wcześniej z Ingardenem. Z Alma Mater odeszli później Andrzej Półtawski i Jan Szewczyk, choć tutaj zachodziły dodatkowe jeszcze okoliczności. W każdym przypadku wymienionych osób Rada Wydziału poniosła porażkę. Największą zapewne w momencie, gdy nie przystała na odczytanie listu Dąmbskiej, akceptując w ten sposób zarzuty sformułowane przez Komisję Kwalifikacyjną o niezgodności nauczania z oficjalną doktryną ideologiczną i złym wpływie na młodzież studencką. Schaff w imię dbałości o jakość nauki polskiej usunął z Uniwersytetu Jagiellońskiego bardzo dobrych dydaktyków i naukowców.

W kolejnym fragmencie wspomnianego listu Morawskiego pojawiają się słowa, które mówią coś jeszcze: „W każdym razie radziłem pani dr M.G. nie wywoływać wilka z lasu. Wszelkie przeciwakcje, za nim [sic!] pojawi się spodziewana nawet akcja, może wywołać najgorsze skutki" ${ }^{12}$. Wynika z tego, że w momencie ich spotkania decyzje jeszcze nie zapadły i można co najwyżej mówić o stanie zagrożenia (,za nim pojawi się spodziewana nawet akcja”). Ponadto Morawski radził, by „nie wywoływać wilka z lasu”, by nie podejmować przeciwakcji, gdyż „może wywołać najgorsze skutki”. Trudno dzisiaj ocenić, czy jego postawa była wyrazem niewiedzy, czy może niechęci do angażowania się w sprawy o podłożu ideologicznym. W każdym razie estetyk podzielał oburzenie Ingardena związane z tym wydarzeniem, nie rozumiał przyczyn zwolnienia Makoty, ale jednocześnie przyznawał, że jest bezsilny. Morawski nie mógł jednak wówczas przypuszczać - relacjonując Ingardenowi spotkanie z Gołaszewską - że w 1968 roku, a więc zaledwie pięć lat później, w konsekwencji wydarzeń marcowych, sam stanie się ofiarą represji politycznych i decyzją innego rządcy nauki polskiej w barwach partyjnych straci pracę na Uniwersytecie Warszawskim ${ }^{13}$.

$10 \quad$ Ibidem, s. 322 (wyróżnienie oryg.).

11 Ibidem, s. 323.

12 List S. Morawskiego do R. Ingardena z 25 stycznia 1964 r. [w:] Cyfrowe Archiwum..., op. cit.

13 Dodajmy na marginesie, że sytuacja - niczym chichot nieodległej w tym przypadku historii - powtórzyła się w odniesieniu do Stefana Żółkiewskiego, który również został relegowany z Uniwersytetu 
Sprawa usunięcia z pracy obu filozofek była dla Ingardena ważna, dlatego wraca do niej raz jeszcze w liście o rok późniejszym, bo z końca listopada 1965 roku. List ten zawiera kilka ważnych wątków, ujawniając przy tym stan napięcia między korespondującymi filozofami. Autor Das Literarische Kunstwerk po raz kolejny powraca w nim do sprawy utraty pracy przez dr Makotę. Odpowiadając na list i jednocześnie podzielając opinię Ingardena, Morawski wyraża bezsilność i nieskrywaną już irytację. Pisze bowiem:

Jeszcze raz p. Makota. O pracy w PAN-ie teraz nie ma mowy. Proponuję cierpliwość. Jeśli w roku następnym (jesień 1966) powstanie Zakład Estetyki w Instytucie Filozofii i Socjologii PAN, można by pomyśleć o „stacjach” (...) w Krakowie, etc. Wtedy powrócimy do sprawy, dobrze? ${ }^{14}$

Morawski musiał wówczas czuć się mocno naciskany przez Ingardena, który zapewne przeceniał możliwości udzielenia pomocy przez kolegę z Warszawy. W kolejnym liście Morawski wyjaśniał nieporozumienie, że Makota byłaby adiunktem, a nie stażystką w stacji PAN-u ${ }^{15}$. Owa „stacja” PAN-u w Krakowie nie powstała, obietnica okazała się więc pusta, choć trudno winić o to Morawskiego. Równocześnie zadeklarował Ingardenowi: „O ile mogę, o tyle wpływam na właściwe odnoszenie się do Pańskich uczniów i zdaję sobie sprawę, iż w estetyce nie ma w tej chwili nic bardziej dojrzałego, przynajmniej w naszych warunkach"16. Z pewnością nie były to zdawkowe pochwały, Morawski był świadomy intelektualnej „mocy” i filozoficznej wagi dorobku samego Ingardena i jego uczniów. Potwierdzeniem życzliwości jest informacja dotycząca jednej z uczennic Ingardena: „Nb. w sprawie pani Gołaszewskiej napisałem długą i pochlebną opinię dla władz najwyższych, by spowodować nareszcie przyznanie jej docentury” ${ }^{17}$. Słówko „nareszcie” sugeruje długi czas starań Gołaszewskiej o docenturę po otrzymaniu habilitacji; tę jednak filozofka dostała zaledwie rok wcześniej. W każdym razie opinia Morawskiego niewiele w tym momencie dała. Gołaszewska otrzymała docenturę w 1969 roku, a więc pięć lat po habilitacji.

\section{Sprawy publikacyjne}

W korespondencji obu filozofów przewijają się sprawy o różnym znaczeniu i zabarwieniu emocjonalnym, inicjujące dyskusje, które mimo pewnego napięcia kończyły się wszak pozytywnie. Wśród poruszanych spraw były: publikacja pokonferencyjna, artykuły w „Studiach Estetycznych”, informacje biuletynowe, recenzje i opinie

Warszawskiego w 1968 r., a który w końcu lat 40. XX w. przyczynił się do usunięcia Ingardena z Uniwersytetu Jagiellońskiego.

14 List S. Morawskiego do R. Ingardena z 30 listopada 1965 r. [w:] Cyfrowe Archiwum..., op. cit.

15 List S. Morawskiego do R. Ingardena z 5 grudnia 1965 r. [w:] ibidem.

16 List S. Morawskiego do R. Ingardena z 30 listopada 1965 r. [w:] ibidem.

17 Ibidem. 
dotyczące materiałów zgłaszanych do „Studiów Estetycznych”. Niezmiennie pozytywna finalizacja wszystkich tych spraw i kwestii nie może dziwić, gdyż Morawski wyrażał szacunek i duże uznanie dla wiedzy i warsztatu Ingardena. Stąd na przykład prośba Morawskiego o recenzję artykułu Jadwigi Sławińskiej, poświęconego zagadnieniom teorii dzieła architektonicznego ${ }^{18}$. Jak wiemy z zachowanej korespondencji, Ingarden uważnie zapoznał się z tym tekstem i przesłał autorce obszerne uwagi krytyczne. Pisał wówczas między innymi do Morawskiego, że:

To jest właśnie, jak sądzę, siła przedstawianych przeze mnie poglądów, a nie ich - jak powtarza wielokrotnie p. Sławińska - „niespójności”. Ustawiać je wszystkie pod jeden strychulec, sprowadzać do jednej tylko koncepcji, to właśnie to, czego starałem się uniknąć. Nie sądzę przy tym, bym wygłaszał istotnie jakieś twierdzenia prowadzące do sprzeczności lub owej „,niespójności”, ale oczywiście nie mogę tego tutaj wykazać19.

Pewnym niemerytorycznym problemem poruszanym w korespondencji Ingardena i Morawskiego była kwestia publikacji referatów pokongresowych, która przewija się przez kilka listów z 1964 roku. Samo w sobie mogłoby to dziwić, gdyby nie dotyczyło wcześniejszych złych doświadczeń Ingardena z redakcjami najpierw „Estetyki”, później „Studiów Estetycznych”. W listach z 8 i 26 maja oraz 3 czerwca 1964 roku (także z 26 sierpnia 1965 roku) pojawia się sprawa referatu z kongresu w Amsterdamie (odbywał się w dniach 24-28 sierpnia 1964 r.) ${ }^{20}$. Morawski listownie poprosił Ingardena o streszczenie jego wystąpienia, by je opublikować w planowanym tomie „Studiów Estetycznych”21. W zamyśle redaktora tom ten miał zawierać wszystkie wystąpienia polskich autorów, a więc poza Morawskim i Ingardenem, także Władysława Tatarkiewicza, Mieczysława Wallisa i Ireny Wojnar.

Sprawa tej publikacji stanęła ponownie w liście z 21 listopada 1964 roku. Ingarden wrócił bowiem do referatu z IV Kongresu w Atenach (wrzesień 1960), wyrzucając bezpośrednio Tatarkiewiczowi - a pośrednio Morawskiemu, który należał do redakcji „Estetyki” - różnicujące decyzje, które dla jednych oznaczały publikację pełnych tekstów, a dla Ingardena tylko streszczenia. Ingarden dodawał jednocześnie, że to o jego plenarnym posiedzeniu ,„potem jeden ze sprawozdawców napisał, że stanowił punkt kulminacyjny kongresu”22. Mimo tak wysokiej oceny „p. Wojnar w swym sprawozdaniu ogłoszonym po francusku w ogóle nawet tytułu jego nie wymieniła"23. Słychać tu ton pretensji, ale także irytacji, lecz trudno to uznać za

18 Zob. J. Sławińska, Uwagi o teorii dzieła architektonicznego Romana Ingardena, „Studia Estetyczne” 1964 , t. 1, s. 235-244.

19 List R. Ingardena do S. Morawskiego z 8 stycznia 1964 r. [w:] Cyfrowe Archiwum..., op. cit.

20 Chodzi o odczyt Ingardena nt. „Das Problem des Systems der ästhetisch relevanten Qualitäten” wygłoszony na V Międzynarodowym Kongresie dla Badań Estetycznych, który odbył się w 1964 roku w Amsterdamie. Zob. też: R.W. Ingarden, Spisy Archiwaliów Romana Witolda Ingardena, „Ruch Filozoficzny" 2020, t. LXXVI, nr 1, s. 49-70. DOI: http://dx.doi.org/10.12775/RF.2020.005.

${ }^{21}$ List S. Morawskiego do R. Ingardena z 8 maja 1964 r. [w:] Cyfrowe Archiwum..., op. cit.

22 List R. Ingardena do S. Morawskiego z 21 listopada 1964 r. [w:] ibidem.

23 Ibidem. 
wyraz małostkowości Ingardena, jeśli zna się jego powojenną biografię zawodową i naukową. W końcu prośba została spełniona, komunikat po przetłumaczeniu go przez Ingardena ukazał się w drugim tomie „Studiów Estetycznych” w 1965 roku.

Ważnym wątkiem w korespondencji z 1965 roku jest jubileusz Tatarkiewicza. Redakcja „Studiów Estetycznych” postanowiła uczcić 80. rocznicę urodzin autora Historii filozofii, przypadającą w kwietniu 1965 roku, poświęcając mu czwarty rocznik czasopisma. W związku z tym wydarzeniem Morawski zaprosił Ingardena do udziału w planowanych uroczystościach i do przesłania artykułu do jubileuszowego tomu ${ }^{24}$. Z planów wydarzenia wynika dość jasno, że Ingarden należał do głównych postaci celebrujących uroczystość, a mimo to opóźniał dostarczenie tekstu. Może zawinił tu sam Morawski, który - wobec listu wcześniejszego - usprawiedliwiając się nadmiarem obowiązków dziekańskich, napisał: „Zawsze esprit de l'escalier. (...) Zapomniałem mianowicie poprosić Go [Ingardena], by wziął udział 4.IV. b.r. w uroczystości ku czci 80-lecia W.T."25. Chcąc zatrzeć to niedobre wrażenie na Ingardenie, zaproponował mu kilka dodatkowych funkcji podczas obchodów jubileuszu:

Mało tego, bardzo Pana proszę w imieniu a) Wydziału 1-ego PAN (od p. St. Żółkiewskiego) b) Polskiego Tow. Filoz. (od p. J. Kotarb.) i c) Dziekanatu alias Rady Wydz. Fil. UW, by zechciał Pan powiedzieć parę okolicznościowych słów jako czołowy estetyk polski. Ponadto łączą Pana przecież z p. WT. więzy koleżeńskie. Chcę rzecz tak zorganizować: I część oficjalna z przemówieniami b. krótkimi: Borkowskiego, Turskiego i Kotarbińskiego oraz trochę dłuższym Pańskim oraz odczytami autoreferatu nauk. teor. (rodzaj samookreślenia sią) WT. odczytam to chyba ja II część oddzielną, późniejszą w węższym gronie, z referatem jubilata oraz potem lampką wina ${ }^{26}$.

W liście z 16 kwietnia 1966 roku Morawski, dotknięty opieszałością Ingardena w związku z inną publikacją, posuwa się do ostrych słów: „Nie przesłał Pan Volkelta? Dlaczego? Nie wyobrażam sobie by moje redaktorskie poczynania zniechęciły Pana do «Studiów...»" ${ }^{27}$ do mnie osobiście" ${ }^{28}$. Niestety nie dowiemy się, o jakie poczynania chodziło, musiały być jednak na tyle mocne, by Morawski pozwolił sobie na ton niemal nakazu: „Oczekuję artykułu”29. Ta postawa przyniosła oczekiwany przez Morawskiego skutek, gdyż Ingarden wysłał tekst dotyczący pojęcia wczucia w rozumieniu Johannesa Volkelta ${ }^{30}$. Morawski, wyraźnie już zadowolony, odpisał wówczas krótko w tej sprawie: „Artykuł jest ładny i interesujący. Zgadzam się z Panem całkowicie co do sprawy «Einfühlen»" "31. Nie byłby jednak sobą, co w tym wypadku znaczy bycie wymagającym redaktorem, gdyby nie zasugerował określonych zmian:

24 List S. Morawskiego do R. Ingardena z 10 grudnia 1965 r. [w:] Cyfrowe Archiwum..., op. cit.

25 List S. Morawskiego do R. Ingardena z [b.d.] 1965 r. [w:] ibidem.

26 List S. Morawskiego do R. Ingardena z 10 grudnia 1965 r., op. cit.

27 List S. Morawskiego do R. Ingardena z 16 kwietnia 1966 r. [w:] ibidem.

28 Ibidem.

29 Ibidem.

30 R. Ingarden, Poglady J. Volkelta na wczucie, „Studia Estetyczne” 1967, t. IV, s. 135-150.

31 List S. Morawskiego do R. Ingardena z [b.d.] 1966 r. [w:] Cyfrowe Archiwum..., op. cit. 
„Proszę nie gniewać się, jeśli zasugeruję, by Pan ewentualnie jeszcze go «zgęścił». Bo jeszcze są typowe dla oratio recta, a w czytaniu daje poczucie, że tekst jest stenogramowym zapisem. Można by np. zrezygnować z tych przypisów niemieckich których treść tak i tak referuje Pan niemal dokładnie w tekście"32. Jednocześnie, by złagodzić swoje uwagi i nie budować złych emocji u Ingardena, zakończył pojednawczo: „Jeszcze raz proszę, by Pańskie jowiszowe oblicze nie zachmurzyło się... Intencje moje były i są bowiem najbardziej przyjacielskie jeśli wolno się tak wyrazić" ${ }^{33}$.

W toku wieloletniej korespondencji między filozofami pojawiały się różne spięcia. Jedna z takich spraw dotyczyła bardzo krytycznych uwag Ingardena o niskim poziomie materiałów publikowanych w „Studiach Estetycznych”. Wnioskujemy o tym pośrednio ze słów Morawskiego napisanych w liście z 30 listopada 1965 roku: „Wreszcie co do «Studiów» w ogóle i mych artykułów. Proszę koniecznie napisać, które artykuły uważa Pan za przykłady analfabetów estetycznych. Nie chcę być wcale zbyt liberalny. Może po prostu niedowidzę"34. Nieznana uwaga Ingardena, którą w tym liście przywołuje Morawski, brzmi jak mocne oskarżenie pod adresem jakości pisma prowadzonego przez autora Absolutu i formy. Nie może więc dziwić wyraźny ton napięcia towarzyszący pytaniu-prośbie, sformułowanej w tym liście przez Morawskiego. Powraca on zresztą do tej sprawy kilka dni później: ,Jeszcze raz proszę o wskazanie mi Jego analfabetycznego artykułu. Pisze Pan o Sikorskim (...), ale takiego autora nie znam i nie przestudiowałem" ${ }^{35}$. Kwestia nie została wyjaśniona i domyślamy się jedynie, że Ingarden chciał ją przemilczeć. Morawski z kolei, odpowiadając ostro Ingardenowi, zastrzega jednocześnie, że jego słowa nie są „zaczepką, ani też wymądrzaniem się" ${ }^{36}$. Czytelnik zostaje tu skazany na domysły, gdyż korespondencja zawiera liczne luki, niemożliwe dzisiaj do zapełnienia.

\section{Sprawy naukowe}

Sprawy naukowe obejmują szeroki zakres bieżących spraw akademickich, jak wyjazdy zagraniczne, prowadzone seminaria, informacje o pisanych pracach magisterskich, doktorskich i habilitacyjnych, pisane recenzje czy wreszcie uwagi o analizach i interpretacjach dzieł wraz z uwagami polemicznymi. Nie wszystkie punkty są dzisiaj możliwe do odtworzenia, stąd też z konieczności zostaną w omówieniu ograniczone do najpełniej zilustrowanych.

32 Ibidem.

33 List S. Morawskiego do R. Ingardena z 16 kwietnia 1966 r., op. cit. Cytowany tutaj list nie ma daty, ale $\mathrm{z}$ informacji w nim zawartych i z omawianego kontekstu można sądzić, że pochodzi prawdopodobnie z maja 1966 r.

34 List S. Morawskiego do R. Ingardena z 30 listopada 1965 r. [w:] ibidem.

35 List S. Morawskiego do R. Ingardena z 5 grudnia 1965 r. [w:] ibidem.

36 List S. Morawskiego do R. Ingardena z 30 listopada 1965 r., op. cit. 


\section{a) Wyjazdy zagraniczne}

Morawski w latach 60. kilkakrotnie wyjeżdżał w ramach stypendiów zagranicznych i w ramach wykładów jako visiting profesor. Celem jego podróży były Wielka Brytania i Stany Zjednoczone (1962), Szwecja (1963), Związek Radziecki (1965), Finlandia (1966) i Niemcy (1967). Nie było to jednak dla niego żadną przeszkodą w podtrzymaniu kontaktów z Ingardenem. W roku 1962 Morawski przebywał na stypendium w Wielkiej Brytanii, skąd następnie wyjechał do Stanów Zjednoczonych, gdzie na kilku uniwersytetach prowadził wykłady z filozofii marksistowskiej i współczesnej polskiej estetyki. W ramach tej drugiej dyscypliny dużo uwagi poświęcał Ingardenowi i jego poglądom, nawet jeśli, co sam przyznał, nie zawsze się z nimi zgadzał. Co ciekawe, autor Absolutu i formy określił sam siebie w jednym z listów „mimowolnym ambasadorem” Ingardena ${ }^{37}$. Donosił też ze Stanfordu, że zgłosił się do niego doktorant „po konsultacje (...) z Ingardena” ${ }^{\text {", }}$, wyrażając przy tym uznanie i radość z faktu, że Ingardena „myśl wędruje przez świat” ${ }^{39}$.

Podobna sytuacja miała miejsce cztery lata później, gdy Morawski spędził trzy miesiące letnie w USA, skąd donosił w podobnym tonie, jak czynił to poprzednio: „Oczywiście pytano mnie o Pana w Berkeley. Profesorowie konkretnie o Pana, studenci o fenomenologię - a ja znów o Pana estetyce, którą jak Pan wie, miłuję - niemiłuję"40. I znowu podobnie było w Berlinie, gdzie „dużo było pytań o Pana. Napisano tam pracę doktorską o Panu. Doktorant bardzo inteligentny" "11. I wreszcie podobnie było w Moskwie. Morawski pisze tu o swoich wykładach poświęconych Heideggerowi i Malraux, które traktuje ,jako antypody estetyki egzystencjalnej”42, dodając zarazem, że zainteresowanie Husserlem jest duże. W tym kontekście informuje Ingardena, że ten jest rozpoznawany jako estetyk, którego dzieła są czytane. Choć zgodnie z przytoczonymi już fragmentami poglądy Ingardena były dla autora Absolutu i formy „,miłe - niemiłe” zarazem, to jednocześnie Morawski zapewnia, że znajduje „coraz więcej wspólnych rozwiązań z [Ingardenem] mimo iż [jego] metoda jest mi daleka"44.

Niech za puentę stosunku Morawskiego do Ingardena posłużą słowa tego pierwszego, wyrażone przy innej okazji. W liście z 3 czerwca 1964 roku Morawski informuje Ingardena o pracy magisterskiej Katarzyny Graff, w której autorka stawia tezę, że estetyka Ingardena funkcjonuje tylko w świetle jego filozofii. Morawski odrzucił taki wniosek i można sądzić, że ta opinia była pretekstem do wyrażenia wielkiego uznania i bardzo pozytywnej oceny dokonań Ingardena. Napisał bowiem: „Dla

37 List S. Morawskiego do R. Ingardena z 3 stycznia 1962 r. [w:] Cyfrowe Archiwum..., op. cit.

38 List S. Morawskiego do R. Ingardena z 5 lipca 1962 r. [w:] ibidem.

39 Ibidem.

40 List S. Morawskiego do R. Ingardena z 9 października 1966 r. [w:] ibidem.

${ }^{41}$ List S. Morawskiego do R. Ingardena z 28 czerwca 1967 r. [w:] ibidem.

42 List S. Morawskiego do R. Ingardena z 17 listopada 1965 r. [w:] ibidem.

43 List S. Morawskiego do R. Ingardena z 9 października 1966 r. [w:] ibidem.

44 List S. Morawskiego do R. Ingardena z 30 listopada 1965 r. [w:] ibidem. 
mnie Pański geniusz polega na tym, że dotarł Pan do prawd, które funkcjonują niezależnie od Pańskich przesłanek filozoficznych. W tym sensie «ingardenistami» w jakiejś mierze są wszyscy polscy (i nie tylko) współcześni estetycy. Nawet ci, co Pana zwalczają"45. Nie była to li tylko uprzejmość naukowca. Morawski, choć nie należał do przeciwników Ingardena, z pewnością był jego oponentem merytorycznym.

\section{b) Recenzje}

Recenzje rozpraw na stopnie naukowe dotyczyły następujących osób: Stanisława Cieniawy, Jerzego Gałeckiego, Katarzyny Graff, Piotra Graffa i Krystyny Wójcik. Omawiane w niniejszym artykule listy filozofów poświęcone sprawom recenzji pokazują wzajemne oczekiwania, naciski, a wreszcie stopień uprzejmości naukowców, których efektem były napisane przez nich merytoryczne opinie.

Pierwszy list Morawskiego do Ingardena, rozpoczynający zresztą omawiany zbiór korespondencji obu badaczy, dotyczy w całości problematyki naukowej, poświęcony jest bowiem rozprawie habilitacyjnej Jerzego Gałeckiego ${ }^{46}$. Morawski przedstawia swoje uwagi w kolejnych punktach, z których kilka ma duży ciężar gatunkowy. Mimo wyczulenia autora ,na istotną problematykę związaną z analizą metody i przedmiotu estetyki” "47, jak i ,zmysł analityczno-opisowy”48, co „wyniósł chyba ze szkoły fenomenologicznej"49, wszystko to „prowadzi go czasem na manowce (...) zbytecznie skomplikowanych wniosków i «sekcji»"50. Ponadto Morawski zarzuca Gałeckiemu, że jego praca nie ma nic wspólnego z estetyką, gdyż dotyczy metaestetyki, zastosowano w niej słabe narzędzia metodologiczne i wreszcie w sposób zaskakujący postawiono główny problem, to jest ,jak możliwa jest estetyka jako nauka?"51. Mimo mocnych uwag krytycznych konkluzja recenzji jest pozytywna, a list kończy życzliwa sugestia, by Gałecki wydał jednak książkę w wydawnictwie naukowym, po uwzględnieniu krytycznych uwag recenzentów. Autor skorzystał z tej rady, bo jego książka ukazała się rok później w Wydawnictwie Literackim z przedmową Ingardena, co znacząco podniosło jej status naukowy ${ }^{52}$.

Najwięcej czasu zajęła obu badaczom sprawa recenzji rozprawy doktorskiej Piotra Graffa, o której pisali w korespondencji w latach 1966-196753. Ingarden nie chciał

45 List S. Morawskiego do R. Ingardena z 3 czerwca 1964 r. [w:] ibidem.

46 Recenzja S. Morawskiego, Przedmiot i metoda estetyki [rozszerzona rec. książki: J. Gałecki, Problematyka estetyki, Kraków 1962, ss. 198], „Studia Filozoficzne” 1963, nr 3-4, s. 175-205.

47 List S. Morawskiego do R. Ingardena z 7 grudnia 1961 r. [w:] Cyfrowe Archiwum..., op. cit.

48 Ibidem.

49 Ibidem.

50 Ibidem.

51 Ibidem.

52 J. Gałecki, Problematyka estetyki. Przedmiot i metoda, Wydawnictwo Literackie, Kraków 1962.

53 Pierwsza wzmianka na temat recenzji pracy Graffa pojawia się w kartce pocztowej Morawskiego z lipca 1966 r. Zob. List S. Morawskiego do R. Ingardena z 16 lipca 1966 r. [w:] Cyfrowe Archiwum..., op. cit. 
jej przyjąć, opóźniał sprawę, próbując się wywikłać z prośby kolegi. Częściową przyczyną takiej postawy Ingardena mogła być zachowana w pamięci sprawa sprzed kilku lat, o której pisał do Tatarkiewicza: „Czy znasz jakiegoś p. Graffa? Wczoraj pisał do mnie Morawski proponując, by się dla niego postarać o asystenturę u mnie, jako formę stypendium, bo podobno koniecznie chce studiować u mnie estetykę. Podejrzewam, że to jeszcze jedna wtyczka" ${ }^{54}$. Z pewnością chęć odmowy wynikała również z wielkiej ilości pracy, którą Ingarden miał do wykonania.

Morawski wykorzystywał jednak wszelkie dostępne mu sposoby, aby otrzymać od Ingardena recenzję pracy Graffa. Powoływał się na relacje przyjacielskie, naukowe, a wreszcie też dziekańskie, przywoływał autorytet Leszka Kołakowskiego, który już dostarczył recenzję, w końcu podawał nieprzekraczalne terminy, na przykład ostatni termin Rady Wydziału w liście z 9 czerwca 1967 roku $^{55}$. „Szachował” również Ingardena rozprawą jego doktorantki Krystyny Wójcik, której doktorat miał sam zrecenzować. Pisał bowiem do Ingardena: „Dzisiaj tzn. 16-ego otrzymałem prace p. Wójcik. Za cztery dni wyjeżdżam do USA. Wracam dopiero 1.X. b.r. Praca jest przeraźliwie obfita" ${ }^{56}$. Mimo wyrażonych w liście uwag Morawski niemal natychmiast po powrocie z USA zabrał się do recenzji doktoratu Wójcik ${ }^{57}$. Musiała to być intensywna praca, a Morawski, mimo wątpliwości, zaopiniował rozprawę pozytywnie, by zapewne w grudniu przesłać ją do Ingardena wraz z listem:

Przesyłam recenzję dla p. mgr Wójcik na Pańskie ręce. Namęczyłem się z nią. Jeśli nawet uzna ją Pan za ostrą, niech będzie dowodem, że nie potraktowałem jej powierzchownie. Muszę przyznać, że praca nie wydaje mi się atrakcyjna. A im więcej czytam Pańskich uczniów, tym więcej dostrzegam nie tylko Pańską wielkość, ale i zalety Pana fenomenologii ${ }^{58}$.

W tej sytuacji Ingarden nie mógł odmówić recenzji doktoratu Graffa, choć nie oddawał pola bez walki. Na ostatnią radę czerwcową wysłał telegram, że pracę zaopiniuje pozytywnie, samą zaś recenzję wyśle w połowie lipca, wykorzystując trzy ustawowe miesiące na jej napisanie. Wskazywał przy okazji rozliczne przeszkody, a to odczyt w Instytucie Sztuki, a to konieczność przeczytania książki Bensego, a to wreszcie charakter samej rozprawy, która „okazała się bowiem nie z estetyki, (...) lecz z ogólnej teorii wartości, a naprawdę to nie z teorii wartości, lecz z socjologicznie ujętej prakseologii" ${ }^{59}$. W konkluzji Ingarden stwierdza, że cała

(...) rozprawa znajduje się tedy na peryferii mojej kompetencji, wymaga ode mnie gruntownego przemyślenia różnych spraw. (...) Przeraża mię też naczelna teza rozprawy, która wydaje mi się b. niebezpieczną dla rozwoju kultury. Że wydaje mi się fałszywa, to nie odgrywa dla mnie

${ }_{54}$ List R. Ingardena do W. Tatarkiewicza z 9 maja 1961 r. [w:] ibidem.

55 List S. Morawskiego do R. Ingardena z 9 czerwca 1967 r. [w:] ibidem.

56 List S. Morawskiego do R. Ingardena z 16 lipca 1966 r., op. cit.

57 List S. Morawskiego do R. Ingardena z 9 października 1966 r., op. cit.

58 List S. Morawskiego do R. Ingardena z [b.d.] 1966 r. [w:] ibidem. Obrona doktorska mgr Wójcik odbyła się 21 marca 1967 r. w Krakowie.

59 List R. Ingardena do S. Morawskiego z 23 czerwca 1967 r. [w:] ibidem. 
jako recenzenta roli, albowiem dopuszczam zawsze, iż autor rozprawy przeze mnie recenzjonowanej ma prawo zajmować stanowisko wręcz przeciwne stanowisku mojemu ${ }^{60}$.

W liście o trzy dni późniejszym Ingarden koryguje swoje stwierdzenie o prakseologii, które powstało na podstawie tylko rozdziału pierwszego. W tym liście pojawia się jednak inny, całkiem poważny zarzut. Otóż Ingarden pisze w nim, że

Graff kilkakrotnie w notach wymienia moją prace i nazwisko, z tego prawie bez wyjątku fałszywie podając moje twierdzenia, albo niewłaściwie wymieniając daną pracę, gdy należało wymienić koniecznie inną. Raz polemizuje ze mną na temat nazw ogólnych i jednostkowych, ale rozwiązanie, które daje od siebie znajduje się parę kartek dalej w Das literarische Kunstwersk, tylko on już nie doczytał tego ${ }^{61}$.

Morawski, odpowiadając na list Ingardena, nie odnosi się do tych błędów warsztatowych Graffa, zauważa tylko, że Kołakowski miał również sporo refleksji krytycznych. Sam również ma wątpliwości „czy ów 'mariaż' socjologiczno-fenomenologiczny" da się utrzymaćc2.

Pozostała część zachowanej korespondencji z 1967 roku dotyczy w dużym stopniu recenzji rozprawy mgr. Graffa. Wnikliwa i drobiazgowa recenzja pracy Graffa, którą przedstawił Ingarden, była bardzo krytyczna. Stąd Morawski w kartce pocztowej z 12 sierpnia donosił Ingardenowi, że „Piotr G. jest zdruzgotany Pańską recenzją. Dobrze mu to zrobi, ale szkoda, że nie skontaktuje się teraz z Panem. W grudniu prześle Panu swą odpowiedź" 63 . W każdym razie cały proces zakończył się dla doktoranta pozytywnie, wspomniany mariaż dał się utrzymać i obrona odbyła się we wrześniu, choć bez obecności Ingardena ${ }^{64}$. On sam w liście do Tatarkiewicza dał wyraz niechęci do pisania tej i w ogóle recenzji, w czym miał swój udział wypadek, jakiemu uległ podczas spaceru w Rabce. Pisał w liście do Tatarkiewicza: „muszę tracić wiele cennego czasu na pisanie recenzji z rozprawy doktorskiej Graffa" ${ }^{65}$, którą jak już wspomniano przyjął mimo licznych zastrzeżeń. „Pisanie takich recenzji - konkludował powinno być zakazane jako zupełnie niepotrzebna strata czasu dla profesorów"66.

Warto ponadto odnotować, że w jednym przypadku Ingarden stanowczo odmówił wykonania recenzji. Miało to miejsce w związku z prośbą Morawskiego o zaopiniowanie rozprawy doktorskiej Stanisława Cieniawy pt. „Postawa estetyczna i artystyczna”. W liście do Ingardena w tej sprawie Morawski zawarł ważną, jak można sądzić, informację, że posiada już dwie recenzje tej pracy, autorstwa Stefana Szumana i Bogdana Suchodolskiego. W tym też kontekście dodawał, że „trzeba recenzji estetyka

\footnotetext{
60 Ibidem.

61 List R. Ingardena do S. Morawskiego z 26 czerwca 1967 r. [w:] ibidem.

62 List S. Morawskiego do R. Ingardena z 28 czerwca 1967 r. [w:] ibidem.

63 List S. Morawskiego do R. Ingardena z 12 sierpnia 1967 r. [w:] ibidem.

64 Ibidem.

65 List R. Ingardena do W. Tatarkiewicza z 13 lipca 1967 r. [w:] ibidem.

66 Ibidem.
} 
sensu stricte" ${ }^{67}$. Ingarden pozostał jednak nieugięty, choć jego odmowa postawiła Morawskiego w trudnej sytuacji - czego nie omieszkał przyjacielowi wypomnieć ${ }^{68}$.

$\mathrm{Na}$ koniec należy przytoczyć przypadek jeszcze jednej recenzji, bo dotyczącej podoktorskiej książki dr Makoty. Opublikowany w „Studiach Estetycznych” krytyczny tekst dotyczący pracy Makoty stał się kolejnym przyczynkiem do wymiany (często ostrych) uwag między filozofami. Ingarden - jak możemy się domyślić - zarzucił Morawskiemu grzecznościowe zakończenie opinii po zasadniczo negatywnej recenzji. Morawski w odpowiedzi na te uwagi wyjaśnił: „wydawało mi się że [recenzja] jest pozytywna mimo polemiki. Tak bowiem myślę [o] tej książce. Zakończenie nie jest wcale «grzecznościowe» - jest swego rodzaju uzasadnieniem, dlaczego tyle miejsca i czasu poświęciłem właśnie tej pracy. Nie mam ochoty ani czasu na zajmowanie się racjami lichymi" ${ }^{69}$. Możemy się jedynie domyślać treści listu Ingardena i zawartych w nim uwag o charakterze zarzutów i pretensji. Nie sposób omawiać tu cała recenzję, warto jednak choć krótko skomentować uwagi obu filozofów.

Morawski na dziesięciu stronach napisanych drobnym drukiem przedstawił szczegółową i rzeczową recenzję książki Makoty. Recenzja zawiera wiele uwag krytycznych, które w równej mierze trafiają w autorkę, jak i w fenomenologiczną metodologię. W obu przypadkach, choć z różną siłą „rażenia”, pośrednio (i bezpośrednio) trafiają one w samego Ingardena, który musiał się poczuć dotknięty zarzutami. Jednak po zapoznaniu się z recenzją należy przyznać rację Morawskiemu i przedstawianym przez niego argumentom. Można też zrozumieć jego zniecierpliwienie, a może nawet zmęczenie, ciągłym przekonywaniem Ingardena o swoim szacunku dla niego. Autor Głównych nurtów estetyki XX wieku kończy swoją opinię mocnym słowem, w którym nie znajdujemy śladu czczego pochlebstwa: „Książka J. Makoty dowodzi, że szkoła jej świetnego nauczyciela, Romana Ingardena, jest jedną z najlepszych współczesnych szkół myślenia estetycznego. Można się z nią nie zgodzić, ale trzeba wpierw podjąć próbę uporania się z nią, by znaleźć jakiekolwiek rozwiązania wytrzymujące konkurencję z zawsze owocnym i wnikliwym stawianiem zagadnień przez polski ośrodek fenomenologiczny"

Niech za podsumowanie niniejszej prezentacji korespondencji dwóch wybitnych polskich filozofów posłuży zaskakujący wątek. Morawski, w liście z 24 kwietnia 1966 roku, odnosi się do zapowiedzianego przez Ingardena odejścia od estetyki: „Smutno przeczytać, że chce Pan zamknąć swe rachunki z estetyką”. Dodaje przy tym, że postanowił tym razem nie uwierzyć Ingardenowi i „kusić Go nadal różnymi

67 List S. Morawskiego do R. Ingardena z 13 grudnia 1965 r. [w:] ibidem.

68 List S. Morawskiego do R. Ingardena z [b.d.] grudnia 1965 r. [w:] ibidem.

69 List S. Morawskiego do R. Ingardena z 30 listopada 1965 r. [w:] ibidem.

70 Morawski bowiem opublikował w 1965 r. w „Studiach Estetycznych” recenzję książki Makoty, do której Ingarden odniósł się - jak przypuszczamy - w jednym z niezachowanych listów. Zob. S. Morawski, O klasyfikacji sztuk, „Studia Estetyczne” 1965, t. 2, s. 345. 
propozycjami. Choćby planowaną regulacją matematycznych metod w estetyce"71. Można domniemywać, że chodzi tu o propozycję Maxa Bensego, o której razem dyskutowali, o czym wiemy ze śladowych pozostałości w listach. Teoria estetyczna Ingardena była bez wątpienia tym, co Morawski cenił najbardziej w jego filozoficznym dorobku. Wyraził to dobitnie, w życzeniach składanych Ingardenowi z okazji Nowego Roku 1966, pisząc: „Życzę Najlepszego Roku - dla estetyki polskiej i światowej znowu kilku choćby Pańskich artykułów z tej dziedziny"72.

Ingarden zrealizował swoją zapowiedź i ,zamknął swe rachunki z estetyką”, konto filozofii pozostawił jednak otwarte. Należy pamiętać, że w ostatnich czterech latach życia był bardzo aktywny naukowo. Publikował nowe książki (Przeżycie - dzieło - wartość), wznawiał wcześniej wydane (Studia z estetyki), czuwał nad publikacją ponad 20 tłumaczeń swoich prac, spędził krótki czas w Liège, skąd po raz drugi wyjechał na jesienne wykłady w Oslo (1967); dwukrotnie przebywał w Wiedniu (1968), pierwszy raz w kwietniu, by odebrać przyznaną mu Nagrodę im. Herdera, i drugi raz we wrześniu, by wziąć udział w XIV Międzynarodowym Kongresie Filozofii z referatem Ästhetik und Kunstphilosophie; wygłosił cykl wykładów w Amsterdamie (1969). W tym czasie Ingarden był równie aktywny naukowo na terenie Polski. Wśród wielu wyjazdów i wykładów dwa z nich, jak się wydaje, szczególnie zasługują na uwagę. W kwietniu 1968 roku na zaproszenie kardynała Karola Wojtyły wziął udział w konferencji poświęconej Edycie Stein, bliskiej przyjaciółce z lat studiów w Niemczech. Kilka miesięcy później, we wrześniu tego samego roku, wziął udział w Konferencji w Toruniu, zorganizowanej z okazji jubileuszu gimnazjum, w którym nauczał w okresie przedwojennym. Był to emocjonalny powrót do czasów, w których ciężko pracował, walcząc o godną realizację obranego celu naukowego. Czterdzieści lat później, u kresu swojego życia, poddawany był równie ciężkim doświadczeniom zawodowym.

\section{Bibliografia}

Czakon D., Michna N.A., Roman Ingarden-życie i dzieło w subiektywnym ujęciu [w:] L. Sosnowski (red.), Spotkania. Roman Ingarden we wspomnieniach, Księgarnia Akademicka, Kraków 2020, s. 18-30.

Gałecki J., Problematyka estetyki. Przedmiot i metoda, Wydawnictwo Literackie, Kraków 1962.

Gołaszewska M., Istota i istnienie wartości. Studium o wartościach estetycznych na tle sytuacji aksjologicznej, Państwowe Wydawnictwo Naukowe, Warszawa 1990.

${ }^{71} \quad$ List S. Morawskiego do R. Ingardena z 24 kwietnia 1966 r. [w:] Cyfrowe Archiwum..., op. cit. Coś było na rzeczy i zapewne Ingarden wykazywał zainteresowanie filozofią matematyki, a szczególnie możliwościami jej zastosowania w estetyce. W końcu 1968 r. dyskutował te sprawy z Danutą Gierulanką, wrócił także do nich na początku 1970 r. w dwóch odczytach (posiedzenia PTF) o poznaniu apriorycznym.

72 List S. Morawskiego do R. Ingardena z [b.d.] grudnia 1965 r. [w:] ibidem. 
Gołaszewska M., Świadomość piękna. Problematyka genezy, funkcji, struktury i wartości w estetyce, Państwowe Wydawnictwo Naukowe, Warszawa 1970.

Ingarden R., Poglady J. Volkelta na wczucie, „Studia Estetyczne” 1967, t. IV, s. 135-150.

Ingarden R., Spisy Archiwaliów Romana Witolda Ingardena, „Ruch Filozoficzny” 2020, t. LXXVI, nr 1, s. 49-70. DOI: http://dx.doi.org/10.12775/RF.2020.005.

Kuliniak R., Pandura M., Roman Witold Ingarden (1893-1970), „Przegląd Filozoficzny Nowa Seria" 2020, nr 29 (4), s. 13-52.

List R. Ingardena do W. Tatarkiewicza z 9 maja 1961 r., Cyfrowe Archiwum Romana Ingardena (dostęp: 4.04.2021).

List S. Morawskiego do R. Ingardena z 7 grudnia 1961 r., Cyfrowe Archiwum Romana Ingardena (dostęp: 4.04.2021).

List S. Morawskiego do R. Ingardena z 3 stycznia 1962 r., Cyfrowe Archiwum Romana Ingardena (dostęp: 4.04.2021).

List S. Morawskiego do R. Ingardena z 5 lipca 1962 r., Cyfrowe Archiwum Romana Ingardena (dostęp: 4.04.2021).

List S. Morawskiego do R. Ingardena z 2 stycznia 1964 r., Cyfrowe Archiwum Romana Ingardena (dostęp: 4.04.2021).

List R. Ingardena do S. Morawskiego z 8 stycznia 1964 r., Cyfrowe Archiwum Romana Ingardena (dostęp: 4.04.2021).

List S. Morawskiego do R. Ingardena z 25 stycznia 1964 r., Cyfrowe Archiwum Romana Ingardena (dostęp: 4.04.2021).

List S. Morawskiego do R. Ingardena z 8 maja 1964 r., Cyfrowe Archiwum Romana Ingardena (dostęp: 4.04.2021).

List S. Morawskiego do R. Ingardena z 3 czerwca 1964 r., Cyfrowe Archiwum Romana Ingardena (dostęp: 4.04.2021).

List R. Ingardena do S. Morawskiego z 21 listopada 1964 r., Cyfrowe Archiwum Romana Ingardena (dostęp: 4.04.2021).

List S. Morawskiego do R. Ingardena z 17 listopada 1965 r., Cyfrowe Archiwum Romana Ingardena (dostęp: 4.04.2021).

List S. Morawskiego do R. Ingardena z 30 listopada 1965 r., Cyfrowe Archiwum Romana Ingardena (dostęp: 4.04.2021).

List S. Morawskiego do R. Ingardena z 5 grudnia 1965 r., Cyfrowe Archiwum Romana Ingardena (dostęp: 4.04.2021).

List S. Morawskiego do R. Ingardena z 10 grudnia 1965 r., Cyfrowe Archiwum Romana Ingardena (dostęp: 4.04.2021).

List S. Morawskiego do R. Ingardena z 13 grudnia 1965 r., Cyfrowe Archiwum Romana Ingardena (dostęp: 4.04.2021).

List S. Morawskiego do R. Ingardena z [b.d.] 1965 r., Cyfrowe Archiwum Romana Ingardena, (dostęp: 4.04.2021).

List S. Morawskiego do R. Ingardena z [b.d.] grudnia 1965 r., Cyfrowe Archiwum Romana Ingardena (dostęp: 4.04.2021).

List S. Morawskiego do R. Ingardena z 16 kwietnia 1966 r., Cyfrowe Archiwum Romana Ingardena (dostęp: 4.04.2021).

List S. Morawskiego do R. Ingardena z 24 kwietnia 1966 r., Cyfrowe Archiwum Romana Ingardena (dostęp: 4.04.2021). 
List S. Morawskiego do R. Ingardena z 16 lipca 1966 r., Cyfrowe Archiwum Romana Ingardena (dostęp: 4.04.2021).

List S. Morawskiego do R. Ingardena z 9 października 1966 r., Cyfrowe Archiwum Romana Ingardena (dostęp: 4.04.2021).

List S. Morawskiego do R. Ingardena z [b.d.] 1966 r., Cyfrowe Archiwum Romana Ingardena (dostęp: 4.04.2021).

List R. Ingardena do S. Morawskiego z 25 maja 1967 r., Cyfrowe Archiwum Romana Ingardena (dostęp: 4.04.2021).

List S. Morawskiego do R. Ingardena z [b.d.] 1967 r., Cyfrowe Archiwum Romana Ingardena (dostęp: 4.04.2021).

List S. Morawskiego do R. Ingardena z 9 czerwca 1967 r., Cyfrowe Archiwum Romana Ingardena (dostęp: 4.04.2021).

List R. Ingardena do S. Morawskiego z 23 czerwca 1967 r., Cyfrowe Archiwum Romana Ingardena (dostęp: 4.04.2021).

List R. Ingardena do S. Morawskiego z 26 czerwca 1967 r., Cyfrowe Archiwum Romana Ingardena (dostęp: 4.04.2021).

List S. Morawskiego do R. Ingardena z 28 czerwca 1967 r., Cyfrowe Archiwum Romana Ingardena (dostęp: 4.04.2021)

List R Ingardena do W. Tatarkiewicza z 13 lipca 1967 r., Cyfrowe Archiwum Romana Ingardena (dostęp: 4.04.2021).

List S. Morawskiego do R. Ingardena z 12 sierpnia 1967 r., Cyfrowe Archiwum Romana Ingardena (dostęp: 4.04.2021).

List S. Morawskiego do R. Ingardena z [b.d.], Cyfrowe Archiwum Romana Ingardena (dostęp: 4.04.2021).

Makota J., Studia to nie musztra żotnierska... [w:] L. Sosnowski (red.), Spotkania. Roman Ingarden we wspomnieniach, Księgarnia Akademicka, Kraków 2020, s. 207-222.

Morawski S., O klasyfikacji sztuk, „Studia Estetyczne” 1965, t. 2, s. 335-345.

Morawski S., Przedmiot i metoda estetyki [rozszerzona rec. książki: J. Gałecki, Problematyka estetyki, Kraków 1962, ss. 198], „Studia Filozoficzne” 1963, nr 3-4, s. 175-205.

Perzanowski J., Izydora Dąmbska [w:] J. Miklaszewska, J. Mizera (red.), Złota księga Jubileuszowa Wydziału Filozoficznego Uniwersytetu Jagiellońskiego, Księgarnia Akademicka, Kraków 2000, s. 317-346.

Przybysz P.J., Stefan Morawski 1921-2004 [w:] Portrety Uczonych. Profesorowie Uniwersytetu Warszawskiego po 1945, Warszawa 2016, s. 292-307.

Przybysz P.J., Zeidler-Janiszewka A., Stefan Morawski - wstępny szkic do portretu [w:] S. Morawski, Wybór pism estetycznych, oprac. P.J. Przybysz, A. Zeidler-Janiszewska, Universitas, Kraków 2007, s. VII-LXIV.

Stefan Morawski - estetyk, z którego został 'oczyszczony' UW w r. 68, https://lustronauki. wordpress.com/2009/01/23/stefan-morawski/ (dostęp: 13.04.2021).

Roman Ingarden - życie, Cyfrowe Archiwum Romana Ingardena (dostęp: 4.04.2021).

Sławińska J., Uwagi o teorii dzieła architektonicznego Romana Ingardena, „Studia Estetyczne" 1964, t. 1, s. 235-244.

Sosnowski L., Roman Ingarden wobec problemu malarstwa granicznego [w:] T. Maślanka (red.), Doświadczanie świata. Eseje o myśli Romana Ingardena, Narodowe Centrum Kultury, Warszawa 2020, s. 327-338. 